Journal of Management

Vol. 36 No. 4, July 2010 857-875

DOI: $10.1177 / 0149206309353944$

(C) The Author(s) 2010

\title{
Users as Innovators: A Review, Critique, and Future Research Directions
}

\author{
Marcel Bogers \\ University of Southern Denmark \\ Allan Afuah \\ University of Michigan \\ Bettina Bastian \\ University of Bern
}

\begin{abstract}
What role do users play during innovation? Ever since it was argued that users can also be the sources of innovation, the literature on the role of users during innovation has grown tremendously. In this article, the authors review this growing literature, critique it, and develop some of the research questions that could be explored to contribute to this literature and to the theoretical perspectives that underpin the literature.
\end{abstract}

Keywords: $\quad$ sources of innovation; user innovation; theory, knowledge; co-creation

In a traditional value system model, industry firms (producers or manufacturers) obtain inputs from suppliers to develop and produce goods or services, which they then sell to buyers. These buyers can be intermediate users, who use the products as inputs to their own production processes, or end-consumer users, who use the products to satisfy their personal needs. The role that these users play during innovation of the products that they ordinarily buy from producers has been the subject of research since at least Adam Smith (1776/1999).

\footnotetext{
Acknowledgments: We would like to thank the Journal of Management reviewers, and especially Associate Editor Steven Michael, for constructive comments and suggestions. Marcel Bogers gratefully acknowledges the financial assistance of the Swiss National Science Foundation (grant no. 105512-106932) and the support of the College of Management of Technology (CDM) at EPFL, Switzerland, where an earlier draft of this manuscript was prepared.

Corresponding author: Marcel Bogers, SPIRE Center, Mads Clausen Institute for Product Innovation, University of Southern Denmark, Alsion 2, 6400 Sønderborg, Denmark.
}

E-mail:bogers@mci.sdu.dk 
An early research stream that explored this role showed that users play an important but peripheral role by providing producers with some of the critical inputs that they need to develop and market products that better meet customers' needs (Burns \& Stalker, 1961; Myers \& Marquis, 1969; Rothwell, 1977). Subsequent research went one step further by arguing that users can be the sources of innovation-that users can be innovators too, not just helpers to producers who innovate (von Hippel, 1988). This research stream sparked even more research on the role of users in innovation. Most recently, the research on users as innovators has extended to areas as diverse as industry dynamics, entrepreneurship, firm boundaries, innovation communities, measurement, and policy (e.g., Baldwin, Hienerth, \& von Hippel, 2006; Shah \& Tripsas, 2007; von Hippel, 2005). Given the increasing recognition and importance of users as potential sources of value for firms and society at large (cf. Henkel \& von Hippel, 2005; Prahalad \& Ramaswamy, 2003), we believe it is useful to provide a comprehensive review of the role of users in the innovation process and to link the notion of users as innovators to other literatures in the field of management.

Our first goal in this article is to review the growing literature on the role of users during innovation. Our second goal is to assess the extent to which this research is theory driven, describe which research questions remain unexplored, and suggest future research directions. In writing the article, we reviewed the main journals in management in general and management of technology in particular, as well as other publications that explore the sources of innovation. By analyzing these publications along four key dimensionsresearch questions, methods and findings, theoretical perspectives, and assumptions-we identified different research streams within the literature on the role of users in the innovation process and some of the key unexplored questions in the area. Our article makes two main contributions. First, by providing a comprehensive literature review and deriving potential research questions from the review, we offer the type of background materials that new researchers to the area of users as innovators can use as a base for new research questions. Second, by assessing the theoretical foundations of the literature and pointing out its flaws, we provide a starting point for making contributions not only to the literature on users as innovators but also to the different theoretical perspectives that can be used to investigate innovation questions.

\section{Users as Innovators: The Sources of Innovation}

\section{Empirical Evidence of User Innovation}

One of the earliest examples of users as innovators is given by Adam Smith (1776/1999):

In the first fire-engines, a boy was constantly employed to open and shut alternately the communication between the boiler and the cylinder, according as the piston either ascended or descended. One of those boys, who loved to play with his companions, observed that, by tying a string from the handle of the valve which opened this communication to another part of the machine, the valve would open and shut without his assistance, and leave him at liberty to divert himself with his play fellows. One of the greatest improvements that has been made upon this machine, since it was first invented, was in this manner the discovery of a boy who wanted to save his own labour. (pp. 114-115) 
In the 1960s, several studies provided evidence that users innovate. For example, Enos (1962) documented major innovations in oil refining and found that nearly all important innovations were developed by user firms (intermediate users). In a similar vein, Freeman (1968), in his study in the chemical industry, reported that $70 \%$ of major process innovations originally came from user firms. Moreover, Hollander (1965), in his study on the sources of increased efficiency in DuPont's rayon plants, showed that $80 \%$ of unit cost reductions in the plants are due to minor technical changes implemented by the user firm. Thus, this research shows that users can develop and introduce both minor improvements as well as more radical breakthrough innovations.

However, it was von Hippel's research, beginning in the 1970s, that first explicitly paid attention to the (central) role of users as innovators. In his study of the role of users in the scientific instrument innovation process, he sampled 111 innovations and showed that approximately $80 \%$ of these innovations were invented, prototyped, and first field-tested by users of the instrument (von Hippel, 1976). Thus, he showed that users - rather than producers - can be the major sources of innovation. This seminal work set off a substantial amount of research investigating users as the sources of innovation. In this predominantly empirical literature, there are two main categories of user-innovators: intermediate users and consumer users. Table 1 summarizes these two streams of research along some key dimensions, such as the implied theoretical perspectives and empirical methods used in the research.

\section{Intermediate User as Innovator}

Intermediate users are users such as firms that use equipment and components from producers to produce goods and services. Intermediate users also include, for example, scientists, librarians, webmasters, and surgeons. Studies that show intermediate users as the sources of innovation include sectors as diverse as petroleum processes (Enos, 1962), the chemical industry (Hollander, 1965), scientific instruments (von Hippel, 1976), industrial machinery (Foxall \& Tierney, 1984), applications software (Voss, 1985), semiconductors (von Hippel, 1988), printed circuit CAD software (Urban \& von Hippel, 1988), pipe hanger hardware (Herstatt \& von Hippel, 1992), residential construction (Slaughter, 1993), machine tools (Lee, 1996), convenience stores (Ogawa, 1998), library information systems (Morrison, Roberts, \& von Hippel, 2000), security software (Franke \& von Hippel, 2003), and commercial banking (Oliveira \& von Hippel, 2009).

\section{Consumer User as Innovator}

Recent innovation studies in consumer goods sectors suggest that a significant part of innovation and product development can be traced back to consumer users (von Hippel, 2005). Consumer users - users of consumer goods - are typically individual end customers or a community of end users. These studies, typically in the field of sports-related consumer goods and other leisure-time activities, include research on equipment in extreme sports (Franke \& Shah, 2003), outdoor sports (Lüthje, 2004), mountain biking (Lüthje, Herstatt, \& von Hippel, 2005), kite surfing (Tietz, Morrison, Lüthje, \& Herstatt, 2005), rodeo kayaking 
(Baldwin et al., 2006), sailing (Raasch, Herstatt, \& Lock, 2008), juvenile products (Shah \& Tripsas, 2007), stereo components (Langlois \& Robertson, 1992), automobiles (Franz, 2005), and retail banking (Oliveira \& von Hippel, 2009). This research shows a dominant role of users in the invention process and shows how end users freely develop, share, and diffuse innovative ideas within their communities. The field of open-source software has also been studied to show the role of (communities of) users in the innovation process (von Krogh \& von Hippel, 2003, 2006). Research has particularly investigated the conditions under which open-source software is developed (e.g., Haefliger, von Krogh, \& Spaeth, 2008; Lakhani \& von Hippel, 2003; Shah, 2006). Relatedly, user innovation scholars have recently emphasized the fact that innovation can take place in a distributed way (von Hippel, 2007). Such a distributed innovation system also entails that users share their innovations with other users and with producers (cf. Harhoff, Henkel, \& von Hippel, 2003). Moreover, there is increasing evidence that users are more able not only to innovate for themselves (von Hippel, 2005) but also to commercialize their innovations by becoming "user-entrepreneurs" (Shah \& Tripsas, 2007) or otherwise give rise to a new market niche or industry (Baldwin et al., 2006). For example, Shah and Tripsas show that users often collectively develop and commercialize their innovations within the social context of user communities, while Baldwin et al. show that innovative users and user communities often affect the future organization of an industry and give rise to a dominant design.

\section{Why Do Users Innovate?}

As the review so far demonstrates, users are often the sources of innovation. This raises an important question: Why do (some) users innovate? Two plausible explanations that have been offered are the innovation-related costs and benefits to users.

\section{Costs of Innovation-Related Knowledge Transfer: Sticky Information}

Innovation entails combining technical information or knowledge (which embodies the "solution" knowledge) with knowledge of user needs and translating the combination into new products that the users want. In traditional innovation models, the need information is generated on the user site, while the solution information resides with the producer that searches for information on user needs to incorporate this into the new or existing products it develops. Von Hippel (1994) argues that users are more likely than producers to innovate if knowledge (or information) of user needs is "sticky" - that is, costly to transfer. More precisely, information stickiness is defined as "the incremental expenditure required to transfer that unit of information to a specified locus in a form usable by a given information seeker" (von Hippel, 1994: 430), and it depends on the tacitness of the knowledge that must be transferred, the amount that must be transferred, and the absorptive capacities of the transferring parties (cf. Cohen \& Levinthal, 1990; Polanyi, 1958; Rosenberg, 1982). Information stickiness is generally used to explain the locus of innovation rather than how producers search for information about users on the market. For example, Ogawa (1998) showed that the user is more likely to perform innovation activities if information about 
Table 1

\section{Users as Innovators: Research Streams}

\begin{tabular}{|c|c|c|}
\hline & Intermediate user as innovator & Consumer user as innovator \\
\hline $\begin{array}{l}\text { Primary research } \\
\text { question(s) }\end{array}$ & $\begin{array}{l}\text { When and why do intermediate users } \\
\text { (such as firms) innovate rather than } \\
\text { producers? }\end{array}$ & $\begin{array}{l}\text { When and why do consumer users innovate } \\
\text { rather than producers? }\end{array}$ \\
\hline Main finding(s) & $\begin{array}{l}\text { Users innovate because their } \\
\text { knowledge is sticky and they expect } \\
\text { to benefit significantly from using } \\
\text { the innovation. }\end{array}$ & $\begin{array}{l}\text { Users innovate because they draw on sticky } \\
\text { and local knowledge, and they expect to } \\
\text { benefit from using and possibly selling } \\
\text { the innovation and from enjoying the } \\
\text { innovation process. }\end{array}$ \\
\hline Implied theoretical & Information processing and learning & Information processing and learning \\
\hline perspectives & $\begin{array}{l}\text { Economic theory (Schumpeterian } \\
\text { rents) }\end{array}$ & Economic theory (Schumpeterian rents) \\
\hline \multicolumn{3}{|l|}{ Implied assumptions } \\
\hline \multirow[t]{2}{*}{ Actors } & $\begin{array}{l}\text { Firms are boundedly rational and have } \\
\text { limited absorptive capacity. }\end{array}$ & $\begin{array}{l}\text { Individuals are boundedly rational. } \\
\text { Users are utility maximizers. }\end{array}$ \\
\hline & $\begin{array}{l}\text { Economic actors are rent-seekers and } \\
\text { thus profit maximizers but } u \text { sers can } \\
\text { also be utility maximizers. }\end{array}$ & $\begin{array}{l}\text { Users freely reveal their knowledge and } \\
\text { innovations. }\end{array}$ \\
\hline Knowledge & $\begin{array}{l}\text { Knowledge is tacit and context } \\
\text { specific. }\end{array}$ & $\begin{array}{l}\text { Knowledge is tacit, locally available, and } \\
\text { path dependent. }\end{array}$ \\
\hline $\begin{array}{l}\text { Main research methods } \\
\text { (type of data) }\end{array}$ & $\begin{array}{l}\text { Case studies: interviews, } \\
\text { questionnaires, and archival data } \\
\text { (qualitative and quantitative) }\end{array}$ & $\begin{array}{l}\text { Case studies: interviews, questionnaires, } \\
\text { and archival data (qualitative and } \\
\text { quantitative) }\end{array}$ \\
\hline Main unit of analysis & Innovations or problems & $\begin{array}{l}\text { Innovative users and communities } \\
\text { of users }\end{array}$ \\
\hline \multirow[t]{4}{*}{ Key unexplored questions } & $\begin{array}{l}\text { Do intermediate users (user firms) } \\
\text { innovate more in some industries } \\
\text { than in others? Why? }\end{array}$ & $\begin{array}{l}\text { In which industry segments can we expect } \\
\text { innovation by users to be more prevalent } \\
\text { than in other segments? }\end{array}$ \\
\hline & $\begin{array}{l}\text { What does a user firm's profit } \\
\text { maximization function look like? }\end{array}$ & $\begin{array}{l}\text { What does the user's utility function look } \\
\text { like? }\end{array}$ \\
\hline & $\begin{array}{l}\text { How does user innovation relate to the } \\
\text { modularity of technologies and } \\
\text { organizations? }\end{array}$ & $\begin{array}{l}\text { Which motivations drive users to innovate? } \\
\text { Which costs are involved in user } \\
\text { innovation? }\end{array}$ \\
\hline & $\begin{array}{l}\text { How can a manager promote } \\
\text { innovation by workers? }\end{array}$ & $\begin{array}{l}\text { How does user innovation relate to general } \\
\text { industry and market dynamics? }\end{array}$ \\
\hline $\begin{array}{l}\text { Selected representative } \\
\text { references }\end{array}$ & $\begin{array}{l}\text { Bogers (2009); de Jong \& von Hippel } \\
\text { (2009); Herstatt \& von Hippel } \\
\text { (1992); Lee (1996); Morrison, } \\
\text { Roberts, \& von Hippel (2000); } \\
\text { Ogawa (1998); Riggs \& von Hippel } \\
\text { (1994); Slaughter (1993); Urban \& } \\
\text { von Hippel (1988); von Hippel } \\
\text { (1976, 1988) }\end{array}$ & $\begin{array}{l}\text { Baldwin, Hienerth, \& von Hippel (2006); } \\
\text { Franke \& Shah (2003); Lakhani \& von } \\
\text { Hippel (2003); Lüthje (2004); Lüthje, } \\
\text { Herstatt, \& von Hippel (2005); Raasch, } \\
\text { Herstatt, \& Lock (2008); Shah (2006); } \\
\text { Shah \& Tripsas (2007); Tietz, Morrison, } \\
\text { Lüthje, \& Herstatt (2005); von Hippel } \\
\text { (2005) }\end{array}$ \\
\hline
\end{tabular}


user needs is sticky compared to technical solution information, and vice versa. Furthermore, Lüthje et al. (2005) showed that user-innovators usually utilize "local" information - which they have in their possession or have to generate by themselves - not only to determine their needs but also to develop solutions and innovations to meet their needs. Moreover, the higher the stickiness of solution information held by the producer, the more a user-innovator tends to rely on locally available solution knowledge.

\section{Other Innovation-Related Costs and Expertise}

More generally, innovation costs are influenced by the type and quantity of knowledge that is required to innovate (von Hippel, 2005). Based on unique knowledge and expertise, users effectively create low-cost innovative solutions tailored to solving their unique needs (Franke \& Shah, 2003; Lakhani \& von Hippel, 2003; Slaughter, 1993). Moreover, users' expertise and experience in using a product determines their ability to innovate because expert users in a given product field have correspondingly lower innovation-related costs and are more likely to innovate (Lüthje, 2004). Von Hippel (2005: Chapter 4) furthermore argues that a user's decision to innovate is determined by the agency costs resulting from the misaligned interests between the user (as a principal) and the producer (as an agent). While users want to get precisely what they need, producers want to lower their development costs by incorporating solution elements that are already in house or that can be used for other (potential) users.

\section{Expected Benefit From Innovation}

While especially the sticky information argument explains why the user site is unique with regard to the local knowledge, von Hippel $(1988,2005)$ has long put forward the complementary explanation that the actor (producer or user) who expects to benefit most from innovating will be the innovator - with the appropriability of the innovation benefit as a determinant of the locus of innovation. He argues that users, compared to producers, develop fundamentally different (and functionally novel) innovations because they alone benefit from using the innovation, while they also draw on a different knowledge base. In support of the idea that a user's needs and incentives to innovate are different from those of a producer, Riggs and von Hippel (1994) find that users are more likely than producers to innovate if their expectations of innovation-related benefits are higher. Research also found support for the expectation that innovative users are often so-called lead users (intermediate or consumer) - users who face needs that mainstream users will face months or even years later and who expect to benefit significantly from solving these needs early (von Hippel, 1986, 1988, 2005).

\section{Other Benefits From User Innovation}

Next to benefiting from using the innovation - as an incentive to innovate - some userinnovators might be able to draw profit from selling their innovations as well (e.g., Foxall \& Tierney, 1984; Lee, 1996). And while there is important evidence of users becoming entrepreneurs (Shah \& Tripsas, 2007), a critical condition for user entrepreneurship is the ability of the 
users to first gain appropriate intellectual property protection for their inventions, which can be very weak in many fields (Harhoff et al., 2003). Moreover, as also more recently investigated, yet another way in which users can expect to benefit from their innovations does not relate to the outcome but to the process of innovation, as users can simply enjoy the process of problem solving (Lüthje, 2004; von Hippel, 2005). Besides, there is a more recent interest in the motivations that give rise to innovation by users, not the least in open-source software but in other fields as well (e.g., Benkler, 2006; Franke \& Shah, 2003; Jeppesen \& Frederiksen, 2006). Furthermore, in particular in open-source software, another expected benefit for innovating users relates to career concerns as the participation in an open-source software project might leverage some job opportunities, for example, by building reputation among one's peers (Lakhani \& von Hippel, 2003; Lerner \& Tirole, 2002).

\section{Producers Take Advantage of Users as Innovators}

If, as we have explored so far, users can be innovators, an important question is, How can producers benefit from users' innovations? We divide the research that explores this question into two streams - user as postimplementation adapter and user as source of innovation-related knowledge - which we summarize along key dimensions in Table 2 and briefly review below.

\section{User as Postimplementation Adapter}

The research in this area helps us understand how a producer can take advantage of the fact that users can innovate, by helping these users better adopt the producer's product to meet their needs or those of other users, so that the producer can continue to sell more of the same product. For example, carmakers could facilitate users' ability to add sunroofs, stereos, large tires, and so on so that the firm could sell more cars. Some of the early research in this area explored the changing role of the user in the different phases of an innovation process (e.g., Spital, 1979) presumably so that the producer can know better how to facilitate users' ability to innovate and improve producers' products. For example, Rothwell and Gardiner (1985) developed a framework in which user importance increases in the three subsequent stages of invention, innovation, and reinnovation (cf. Douthwaite, Keatinge, \& Park, 2001; Rice \& Rogers, 1980). Similarly, Leonard-Barton (1988) found that users play an important role in the innovation process after a technology is implemented (cf. von Hippel \& Tyre, 1995). Yet, it remains relatively unexplored how a producer can take advantage of this process of (postimplementation) adaptation by users. Furthermore, this research stream (like earlier ones) largely aims at providing empirical evidence of the role of users in the innovation process without having an explicit theoretical focus.

\section{Users as Source of Innovation-Related Knowledge: CAP, Lead Users, and Co-Creation}

After his early recognition that users can be the sources of innovation, von Hippel (1978) developed an approach to innovation that he called the "customer-active paradigm" (CAP) in which the customer develops the new product idea and takes the initiative to transfer it to 
Table 2

Producers Take Advantage of Users as Innovators: Research Streams

\begin{tabular}{|c|c|c|}
\hline & $\begin{array}{c}\text { User as postimplementation } \\
\text { adapter }\end{array}$ & $\begin{array}{l}\text { User as source of innovation- } \\
\text { related knowledge }\end{array}$ \\
\hline Primary research question(s) & $\begin{array}{l}\text { How do users adapt the technology } \\
\text { they use to better fit their needs } \\
\text { and contexts? }\end{array}$ & $\begin{array}{l}\text { To what extent do users } \\
\text { contribute to a producer's } \\
\text { effectiveness in innovating? }\end{array}$ \\
\hline Main finding(s) & $\begin{array}{l}\text { Because a producer's design is } \\
\text { incomplete, users adapt the } \\
\text { technology to fit their exact } \\
\text { needs and contexts. }\end{array}$ & $\begin{array}{l}\text { Understanding users' needs is } \\
\text { imperative for successful } \\
\text { innovation. } \\
\text { Users can also be used as a source } \\
\text { of solution knowledge. }\end{array}$ \\
\hline Implied theoretical perspectives & Problem-solving and learning & $\begin{array}{l}\text { Information processing and } \\
\text { resource dependence }\end{array}$ \\
\hline \multicolumn{3}{|l|}{ Implied assumptions } \\
\hline Actors & Producers are imperfect agents. & Producers are boundedly rational. \\
\hline Knowledge & Knowledge is context specific. & $\begin{array}{l}\text { Knowledge is context specific } \\
\text { and dispersed. }\end{array}$ \\
\hline $\begin{array}{l}\text { Main research methods (type of } \\
\text { data) }\end{array}$ & $\begin{array}{l}\text { Grounded, case-based research } \\
\text { (mainly qualitative with some } \\
\text { quantitative support) }\end{array}$ & $\begin{array}{l}\text { Grounded and exploratory case } \\
\text { studies (both qualitative and } \\
\text { quantitative) }\end{array}$ \\
\hline Main unit of analysis & $\begin{array}{l}\text { Mainly improvements or problems } \\
\text { (after implementation) }\end{array}$ & $\begin{array}{l}\text { Innovations and innovation } \\
\text { projects }\end{array}$ \\
\hline Key unexplored questions & $\begin{array}{l}\text { How can a producer retrieve the } \\
\text { knowledge about the user's } \\
\text { improvements (innovations)? } \\
\text { How do these improvements } \\
\text { (innovations) flow to other users } \\
\text { (competitors)? } \\
\text { How can a producer enable users' } \\
\text { improvements (innovations)? }\end{array}$ & $\begin{array}{l}\text { What is the optimal boundary } \\
\text { between a producer and a user } \\
\text { in the face of an innovation? } \\
\text { Who owns the property rights of } \\
\text { the knowledge that underpins } \\
\text { improvements and innovation? } \\
\text { How could involving users in the } \\
\text { product development process } \\
\text { harm producers? }\end{array}$ \\
\hline Selected representative references & $\begin{array}{l}\text { Leonard-Barton (1988); Rice \& } \\
\text { Rogers (1980); Rothwell \& } \\
\text { Gardiner (1985); von Hippel \& } \\
\text { Tyre (1995) }\end{array}$ & $\begin{array}{l}\text { Franke \& von Hippel (2003); } \\
\text { Jeppesen (2005); Jeppesen \& } \\
\text { Frederiksen (2006); Lilien, } \\
\text { Morrison, Searls, Sonnack, \& } \\
\text { von Hippel (2002); von Hippel } \\
\text { (1978); von Hippel \& Katz } \\
\text { (2002) }\end{array}$ \\
\hline
\end{tabular}

an interested producer (cf. de Jong \& von Hippel, 2009). He considers the CAP as more appropriate to the industrial innovation process by replacing the "manufacturer-active paradigm," which makes a poor fit with how ideas for most new industrial products are generated. There have also been attempts to extend the CAP, for example by going beyond the inventive role of the user and to integrate the user's entrepreneurial role and thus the commercial diffusion of the innovation (Foxall \& Tierney, 1984). 
While the CAP proposes that users play a more active role in producers' innovation processes, there are ways in which producers can more proactively involve users. One specific way of doing so is by involving lead users, which entails collecting information about both needs and solutions not only from users at the leading edges of the target market but also from users in other markets that face similar problems in a more extreme form (e.g., Lilien, Morrison, Searls, Sonnack, \& von Hippel, 2002). Producers can use lead users to develop breakthrough products that tend to have higher performance and marketplace potential than other innovations (cf. Lüthje \& Herstatt, 2004; von Hippel, 2005).

Moreover, some research has explored how users can be even more active participants during innovation as coproducers of products, services, or value in general (cf. Buur \& Matthews, 2008; Prahalad \& Ramaswamy, 2003; Vargo \& Lusch, 2004). Software is also a common example of joint innovation effort-for instance, agile software development with methodologies such as joint application design, extreme programming, and Scrum, which are fully dependent on frequent user involvement. More generally, because users have a high heterogeneity of need and a high willingness to pay to get exactly the product they want (Franke \& von Hippel, 2003), they can be effectively integrated in the innovation process by enabling them to modify products on their own - thereby transferring certain development tasks and knowledge to the user, rather than trying to locate, screen, and transfer need-related knowledge from the user to the producer (cf. von Hippel, 1994). Co-creation entails enabling users to autonomously experiment and innovate by providing a platform for collaborative innovation, for example by hosting user communities (Jeppesen \& Frederiksen, 2006) or providing "toolkits" for innovation (von Hippel \& Katz, 2002), while the Internet also provides opportunities for engaging users in innovation (Piller \& Walcher, 2006; Sawhney, Verona, \& Prandelli, 2005). Relatedly, some research has more generally explored innovation as a joint or interactive process between producers and users - thereby also stressing the interactive nature of innovation (e.g., Jensen, Johnson, Lorenz \& Lundvall, 2007; Lundvall, 1988; Shaw, 1985).

\section{Critique and Future Research Directions}

While the literature review that we presented above shows the various roles that users can play in innovation, there are still many areas that are unexplored. By presenting this review, we hope to have provided the type of background material that new researchers to the area of users as innovators can use as a base for new research questions. In the following, we provide a critique of this literature and discuss some of the possibly fruitful directions for future research.

\section{Theory and Theoretical Perspectives}

An important shortcoming of the literature on users as innovators is the lack of theory or theoretical perspectives, in particular those related to theories in the management literature. While the main explanation for why users innovate-following microeconomic theory of innovation (cf. Dosi, 1988) - has been that temporary (Schumpeterian) profits or economic rents provide the economic rationale for economic actors to innovate (von Hippel, 1988), it is not necessarily clear 
on what broader theoretical perspectives the user innovation literature draws (see also Tables 1 and 2 for implied theoretical perspectives). This is particularly important because, as indicated in the review, there are different explanations for why users innovate, such as the expected benefits and stickiness hypotheses (Ogawa, 1998; von Hippel, 1988, 1994), the agency costs involved (von Hippel, 2005), and the user's knowledge and expertise (Lüthje, 2004; Lüthje et al., 2005), as well as other explanations such as intrinsic benefits and career concerns (Lakhani \& von Hippel, 2003; Lerner \& Tirole, 2002; Shah, 2006). However, for several reasons, these different explanations do not add up to a coherent theory of why users innovate. First, a theory should clearly explain the why of things (Whetten, 1989). A theory is a statement of the relationships between constructs and variables (Bacharach, 1989). Or, in the words of Sutton and Staw (1995), "Theory is the answer to queries of why. Theory is about connections among phenomena, a story about why acts, events, structure, and thoughts occur" (p. 378). Related to the more general development of innovation theories, there is significant scope to develop a theory of why users innovate. Second, a comprehensive and integrative theory of users as innovators should link different concepts and variables and explain the various relationships (Bacharach, 1989; Sutton \& Staw, 1995; Whetten, 1989). In this vein, a major challenge for user innovation scholars is to develop a more coherent theoretical framework that explains why users innovate. One way to do this is to draw on other theoretical perspectives in management that are used to explore research questions in other fields and use them to explore innovation in general and users as innovators in particular. Some possible useful theoretical lenses include learning and information processing; resource-, capability-, or knowledge-based views of the firm; and evolutionary economic theory, or some combination thereof (e.g., Barney, 1991; Nelson \& Winter, 1982; Nonaka, 1994).

\section{Basic Assumptions}

Since a theory is based on its assumptions, the basic assumptions that underpin a theoretical explanation also need to be well explained and grounded. However, it is not always clear what the underlying basic assumptions are in many studies on users as innovators. For example, it is only implied that actors (users and producers) are boundedly rational (Tables 1 and 2). This can, for instance, be seen in the explanation of sticky information, which has to do with the tacit nature of knowledge and the limited absorptive capacities of economic actors. However, the exact assumptions with regard to the actors' behaviors are not well explained. Nor are the implications of these assumptions for the theory discussed. By explicitly incorporating the underlying assumptions into their research and challenging these assumptions, user innovation scholars can better integrate their work into mainstream management literature. Future research might, for example, explore how the cognitive limitations and boundedly rational search behavior of economic actors affect their decision-making capabilities in the process of innovation (cf. Nelson \& Winter, 1982; Simon, 1965). This is potentially important, as bounded rationality implies that economic actors (users and producers) have different types of search behavior, which can be global or local, based on their existing knowledge and capabilities. For example, following Rosenkopf and Nerkar's (2001) framework of local and global search (or typology of exploration), it can be expected that users' and producers' search behaviors have a different impact on the innovative outcome depending on whether or not they span organizational or technological boundaries. 


\section{Definitions of Users and Innovations}

Given the variety of users, user roles, research contexts, methodologies, and units of analysis (see Tables 1 and 2), it would be easier to compare studies if concepts related to users as innovators are more explicitly defined, for example, as related to the distinction between invention and commercialization (or diffusion). Most studies do not build on this traditional definition of innovation but instead more generally focus on the invention part of the innovation process. Moreover, although it is a general contention that users are particularly good at developing radically new, breakthrough innovations (e.g., Lettl, Herstatt, \& Gemuenden, 2006; Lilien et al., 2002), most research does not get into whether innovation is incremental, radical, architectural, generational, modular, or disruptive, as defined in other studies (e.g., Abernathy \& Clark, 1985; Henderson \& Clark, 1990). It is therefore an important challenge for research in the field of users as innovators to better relate these studies to other research that shows that the type of innovation is an important characteristic with regard to the determinants and impact of an innovation. In this context, it would be informative to see how existing research findings in the literature would change if innovation were seen as invention and commercialization, rather than just as invention, or as incremental or radical (see also below). This is also important because what is radical for the user may not be radical for the supplier, and vice versa (Afuah, 2000).

\section{Sticky Information and Tacit Knowledge}

Moreover, a potentially interesting avenue for future research is to explore how the nature of the innovation - or the nature of the underpinning knowledge, more generally - affects the locus or process of innovation (cf. Nonaka, 1994). For example, although the exact nature of the knowledge is left largely unexplored in user innovation research, the sticky information hypothesis implicitly claims that if users' knowledge is tacit, they are more likely to innovate (von Hippel, 1994). This is important because the transfer of knowledge between a user and a producer is a central issue in exploring the locus of innovation, as innovation entails locating, evaluating, and assimilating information about user needs as well as integrating technical (solution) knowledge into new products that users want (cf. Cohen \& Levinthal, 1990). In contrast to explicit knowledge, tacit knowledge is highly personal and not easily made visible and therefore difficult to articulate, identify, and valuate (cf. Nonaka, 1994; Polanyi, 1958). Tacit knowledge implies that users cannot always express their needs, making it difficult for a producer to innovate. However, a producer is better able to innovate when its (tacit) routine allows the producer to solve a user need and the user's routine relies on using (not inventing) a product. The precise role of tacit knowledge in innovation and the exact conditions that give rise to tacit knowledge (or the other elements of sticky information) for both the user and the producer could be fruitfully explored in future research (cf. Lüthje et al., 2005; von Hippel \& Tyre, 1995).

\section{Radical and Incremental Innovation}

In addition, as users and producers often conduct local searches based on their existing knowledge and capabilities (cf. Rosenkopf \& Nerkar, 2001), it could be expected that producers focus 
on existing capabilities to solve user needs and therefore develop innovations that are competence enhancing (Tushman \& Anderson, 1986) or incremental in the organizational sense (Henderson, 1993). In this case, producers are also more likely to locate and assimilate only the knowledge they consider relevant, and they will therefore not identify radical innovations (based on user needs that deviate from the average user need). On the other hand, users are more likely to be the sources of radical innovation if they have a strong incentive to solve their needs (von Hippel, 1988, 2005). However, another consideration for the incentive to innovate is whether an innovation will disrupt current market positions or even render such linkages obsolete (cf. Abernathy \& Clark, 1985). In other words, is the user's or producer's innovation radical or incremental in the economic sense (Henderson, 1993)? If they have the right information, incumbent producers with a monopoly position are not likely to invest in innovation if it renders their existing position noncompetitive (Gilbert \& Newbery, 1982) or if it cannibalizes existing products (Reinganum, 1983). It might then be more likely that users are the ones that develop radical innovation because they are not hampered by any current market position, as their incentive comes from the expected benefit from using the innovation. If we extend this argument to users who also decide to commercialize their inventions, the logic remains the same because the user, as a new entrant, is not constrained by any linkages with current products or markets (cf. Gans \& Stern, 2003; Shah \& Tripsas, 2007).

\section{Types of Users and User Roles}

As indicated above - and shown in our review (see Tables 1 and 2) — users can be divided into different types, such as consumer users and intermediate users, while there is more generally also a difference between the exact roles that users and producers play during innovation. Although current frameworks such as von Hippel's $(1988,2005)$ typically refer to users as possibly being firms and individuals as well as other types of economic agents, the economic drivers for innovation might be very different for firms as profit maximizers and individuals as utility maximizers. Von Hippel $(1988,2005)$ defines user-innovators as the ones that directly benefit from using their innovations. For user firms, one can only assume that there is a benefit in the ultimate profit that is obtained from the improved production process (cf. Hollander, 1965; Leonard-Barton, 1992). However, there are some indications that users can also benefit in other ways, indicating that users might be better described as utility maximizers. In the case of scientific instruments, for example, Riggs and von Hippel (1994) point out that users and producers each value different attributes of scientific instrument innovations. While "scientist users seek reward in a sense of accomplishment and in the regard of peers with respect to that accomplishment . . manufacturers of scientific innovations seek reward in the form of monetary profit" (Riggs \& von Hippel, 1994: 459-460). Therefore, they find that innovators in scientific instruments tend to develop innovations with a high scientific value rather than a commercial value. More recently, there are also indications that users might enjoy benefits in terms of the process of innovation (intrinsic motivation) or even by selling their products (e.g., Lakhani \& von Hippel, 2003; Shah \& Tripsas, 2007). Therefore, other models of (innovative) behavior by both firms and individuals might be usefully explored. Furthermore, future research could explore the role 
of individuals within user firms (cf. Bogers, 2009; von Hippel \& Tyre, 1995), user communities (cf. Dahlander \& Wallin, 2006; Jeppesen \& Frederiksen, 2006), and distributed forms of innovation at large (cf. von Hippel, 2007).

\section{Locus of Innovation and Industry Dynamics}

This review shows that users, not only producers, are sometimes innovators. But how important is this phenomenon? Following the empirical studies, it appears to be particularly pertinent in sectors with rapidly changing user needs, such as high tech or extreme sports, although there is evidence in low-tech industries and services as well (e.g., Herstatt \& von Hippel, 1992; Oliveira \& von Hippel, 2009; Skiba \& Herstatt, 2009). The changing role of users in innovation should also be investigated, as von Hippel (2005) claims that "users of products or services - both firms and individual consumers - are increasingly able to innovate for themselves" (p. 1; italics added). It also merits further exploration what role users play in different phases of product and industry life cycles (cf. Utterback, 1994). This is an important area for future research, as there is strong evidence that user-innovators can develop radically new technologies, thereby effectively creating a new market niche (in which producers later take over), and that users may more generally play an important role in technology and industry dynamics (Baldwin et al., 2006; Faulkner \& Runde, 2009; Shah $\&$ Tripsas, 2007). Somewhat provocatively, one might even argue that users are the most fundamental sources of innovation, as innovation became institutionalized in manufacturing firms only during the industrial age (cf. Smith, 1776/1999). And furthermore, while there is support for the social value of innovation by users (Henkel \& von Hippel, 2005), it still needs to be further explored how pervasive and generalizable this phenomenon is and to what extent and in what way managers and policy makers should adapt to it.

\section{Implications for Firm Boundaries}

As we also showed in our review (see Table 2), users can serve as providers of innovation-related knowledge to producers. Therefore, the exact role of users in a producer's innovation process, as well as the interactive nature of innovation, merits more investigation - in particular because the relationship between innovation and vertical scope has in general been left largely unexplored (cf. Jacobides \& Billinger, 2006). One important question is, for example, how innovation by users influences the boundary between a producer and user, particularly given that a technological change can affect the optimal boundary of a firm (Afuah, 2001). Moreover, the stickiness or tacitness of the knowledge that underpins the innovation can make it difficult for either the user or the producer (or both) to transfer knowledge to the other party (Ogawa, 1998; von Hippel, 1994). This has more general implications, as innovation - at its core a trial-and-error problem-solving process (von Hippel, 2005) — often involves both suppliers and users of technology (cf. von Hippel \& Tyre, 1995). Similarly, the optimal locus of learning depends on the characteristics of the underpinning knowledge (Pisano, 1994). Thus, firms need to develop tools to understand 
what the exact needs of their users are, how their products are used, and what solutions users develop to solve their needs - all having important implications for the dynamic and knowledge boundaries of the firm (cf. Brusoni, Prencipe, \& Pavitt, 2001; von Hippel \& Katz, 2002).

\section{Open Innovation and Open Source}

One particular way of addressing the implications for firm boundaries is by exploring the conditions under which users can be useful complementors to a producer's internal innovation process. Such research can be related to other research streams that explore the distributed nature of knowledge and innovation. In particular, it can address the role of users in "open" business models based on, for example, crowd-sourcing or open-source software (cf. Ogawa \& Piller, 2006; West \& Gallagher, 2006). More generally, research in open innovation argues that since knowledge is heterogeneously distributed among many agents, producers cannot afford to depend on their own research alone - they are better off also acquiring or licensing inventions from other agents (Chesbrough, 2003). Besides, since complementary assets, which are critical to profiting from innovation (Teece, 1986), are heterogeneously distributed, an innovator may also be better off licensing, codeveloping with, or selling some of its inventions to firms with such assets. An interesting question at the intersection of open innovation and users as innovators is, When is a producer better off obtaining inventions or innovations from a user rather than from other external sources? Another research question is, When are users better off licensing or selling their innovations to producers rather than to other agents with the right complementary assets? Moreover, research on open-source software shows that users can even develop a product without the involvement of a producer (cf. Benkler, 2006). While there is increasing empirical evidence of the antecedents, processes, and impact of open-source innovation-not only in information goods but also in physical goods (e.g., Raasch, Herstatt, \& Balka, 2009; Stuermer, Spaeth, \& von Krogh, 2009) - many questions still remain to be explored. For example, why is it that sometimes users can bypass (traditional) producers, and what does this mean for our understanding of organization theory (cf. von Hippel, 2007)? Also, what are the exact capabilities of users who participate in open-source innovation, and which of these capabilities are derived from using the innovation?

\section{Profiting From User Innovation}

While the literature on producers that (possibly) take advantage of users as innovators (see Table 2) can benefit from the work on open-source and open innovation, there are many more issues that can be explored related to how incumbent producers or manufacturers can profit from user innovations. In particular, the role that intellectual property plays merits further investigation (cf. Harhoff et al., 2003; von Hippel \& von Krogh, 2003). Moreover, while producers can profit from users as innovators by (partly) integrating them into the innovation process, a user innovation can also act as an external shock for an incumbent 
producer. A better understanding of how producers can profit from users as innovators might also explain the role of producers' (bounded) rationality and capabilities in reacting to external technological changes (cf. Hill \& Rothaermel, 2003). Furthermore, one particularly fruitful area for further investigation is how innovation by users relates to the user's or producer's complementary assets, such as distribution channels, specialized capabilities, and complementary technologies (Teece, 1986). While there is empirical support that confirms the value of complementary assets for established firms and the role they play for incumbents to emerge as the winner after innovation changes (Tripsas, 1997), future research can explore how these roles differ for users and producers.

\section{Measurement and Validation}

Finally, it is important for any research stream to validate its propositions and theories empirically. To date, most research exploring users as innovators is based on case studies or other small-sample studies (see Tables 1 and 2), although scholars have more recently begun to conduct large-scale studies - for example, by using surveys (Bogers, 2009; de Jong \& von Hippel, 2009; Lhuillery \& Bogers, 2006) or patent data (Chatterji \& Fabrizio, 2008). In addition, innovation by users might often be minor, especially when derived from learning-by-doing activities, making it more difficult to capture it empirically (cf. von Hippel \& Tyre, 1995). As, for example, acknowledged by Dosi (1988), such informal effort is generally embodied in people and organizations, and its cost is hard to trace. In the words of Rosenberg (1982):

There are many kinds of productivity improvements, often individually small but cumulatively very large, that can be identified as a result of direct involvement in the production process. This is a source of technological innovation that is usually not explicitly recognized as a component of the $R \& D$ process, and receives no direct expenditures - which may be the reason why it is ignored. (pp. 121-122)

Such informal innovation can be contrasted to formal R\&D activities, which are typically considered a main source of innovation in empirical studies (cf. Organization for Economic Cooperation and Development, 1997). In the case of consumer users as innovators, it is even more difficult to get a representative view of the innovative activities because they are not part of systematic innovation surveys (which would entail surveying the entire population of people). In general, the research stream on users as innovators will greatly benefit from empirically testing (on a larger scale) the ideas and propositions that it puts forward, ideally by linking them to existing theories and assumptions (as we argued above).

\section{Conclusion}

In this article, we provided a comprehensive review of the research that explores the role of users in innovation. We pointed out some of the weaknesses of past research and suggested possible future research directions in the area. We hope that, in doing so, we have provided scholars of management a springboard from which they can make deeper and 
further-reaching contributions to theory in the field. The rapid pace of technological change, globalization, and increasing user sophistication means that more and more users will have more and more opportunities to innovate or contribute to producer innovations. This constitutes a great opportunity for researchers to probe deeper into questions about users as innovators. It also constitutes an opportunity to contribute to theoretical perspectives. For example, a better understanding of users as innovators may contribute to an understanding of the sources of resources or capabilities, adding to what we know about the resourcebased view of the firm. Understanding more about the locus of innovation may also help us better understand why firm boundaries can be dynamic.

\section{References}

Abernathy, W. J., \& Clark, K. B. 1985. Innovation: Mapping the winds of creative destruction. Research Policy, 14: $3-22$.

Afuah, A. 2000. How much do your "co-opetitors" capabilities matter in the face of technological change? Strategic Management Journal, 21: 387-404.

Afuah, A. 2001. Dynamic boundaries of the firm: Are firms better off being vertically integrated in the face of a technological change. Academy of Management Journal, 44: 1211-1228.

Bacharach, S. B. 1989. Organizational theories: Some criteria for evaluation. Academy of Management Review, 14: 496-515.

Baldwin, C., Hienerth, C., \& von Hippel, E. 2006. How user innovations become commercial products: A theoretical investigation and case study. Research Policy, 35: 1291-1313.

Barney, J. B. 1991. Firm resources and sustained competitive advantage. Journal of Management, 17: 99-120.

Benkler, Y. 2006. The wealth of networks: How social production transforms markets and freedom. New Haven, CT: Yale University Press.

Bogers, M. 2009. The sources of process innovation in user firms: An exploration of the antecedents and impact of non-R\&D innovation and learning-by-doing. Unpublished doctoral thesis, Ecole Polytechnique Fédérale de Lausanne, Lausanne.

Brusoni, S., Prencipe, A., \& Pavitt, K. 2001. Knowledge specialization, organizational coupling, and the boundaries of the firm: Why do firms know more than they make? Administrative Science Quarterly, 46: 597-621.

Burns, T., \& Stalker, G. M. 1961. The management of innovation. London: Tavistock.

Buur, J., \& Matthews, B. 2008. Participatory innovation. International Journal of Innovation Management, 12: 255-273.

Chatterji, A. K., \& Fabrizio, K. 2008. The impact of users on technological development: The role of physician innovation in the medical device industry. Working paper. Fuqua School of Business, Duke University.

Chesbrough, H. W. 2003. Open innovation: The new imperative for creating and profiting from technology. Boston: Harvard Business School Press.

Cohen, W. M., \& Levinthal, D. A. 1990. Absorptive capacity: A new perspective on learning and innovation. Administrative Science Quarterly, 35: 128-152.

Dahlander, L., \& Wallin, M. W. 2006. A man on the inside: Unlocking communities as complementary assets. Research Policy, 35: 1243-1259.

de Jong, J. P. J., \& von Hippel, E. 2009. Transfers of user process innovations to process equipment producers: A study of Dutch high-tech firms. Research Policy, 38: 1181-1191.

Dosi, G. 1988. Sources, procedures, and microeconomic effects of innovation. Journal of Economic Literature, 26: 1120-1171.

Douthwaite, B., Keatinge, J. D. H., \& Park, J. R. 2001. Why promising technologies fail: The neglected role of user innovation during adoption. Research Policy, 30: 819-836.

Enos, J. L. 1962. Petroleum progress and profits: A history of process innovation. Cambridge, MA: MIT Press.

Faulkner, P., \& Runde, J. 2009. On the identity of technological objects and user innovations in function. Academy of Management Review, 34: 442-462. 
Foxall, G. R., \& Tierney, J. D. 1984. From CAP1 to CAP2: User-initiated innovation from the user's point of view. Management Decision, 22(5): 3-15.

Franke, N., \& Shah, S. 2003. How communities support innovative activities: An exploration of assistance and sharing among end-users. Research Policy, 32: 157-178.

Franke, N., \& von Hippel, E. 2003. Satisfying heterogeneous user needs via innovation toolkits: The case of Apache security software. Research Policy, 32: 1199-1215.

Franz, K. 2005. Tinkering: Consumers reinvent the early automobile. Philadelphia: University of Pennsylvania Press.

Freeman, C. 1968. Chemical process plant: Innovation and the world market. National Institute Economic Review, 45: $29-57$.

Gans, J. S., \& Stern, S. 2003. The product market and the market for "ideas": Commercialization strategies for technology entrepreneurs. Research Policy, 32: 333-350.

Gilbert, R. J., \& Newbery, D. M. G. 1982. Preemptive patenting and the persistence of monopoly. American Economic Review, 72: 514-526.

Haefliger, S., von Krogh, G., \& Spaeth, S. 2008. Code reuse in open source software. Management Science, 54: 180-193.

Harhoff, D., Henkel, J., \& von Hippel, E. 2003. Profiting from voluntary information spillovers: How users benefit by freely revealing their innovations. Research Policy, 32: 1753-1769.

Henderson, R. M. 1993. Underinvestment and incompetence as responses to radical innovation: Evidence from the photolithographic alignment industry. Rand Journal of Economics, 24: 248-270.

Henderson, R. M., \& Clark, K. B. 1990. Architectural innovation: The reconfiguration of existing product technologies and the failure of established firms. Administrative Science Quarterly, 35: 9-30.

Henkel, J., \& von Hippel, E. 2005. Welfare implications of user innovation. Journal of Technology Transfer, 30: 73-87.

Herstatt, C., \& von Hippel, E. 1992. From experience: Developing new product concepts via the lead user method: A case study in a "low-tech" field. Journal of Product Innovation Management, 9: 213-221.

Hill, C. W. L., \& Rothaermel, F. T. 2003. The performance of incumbent firms in the face of radical technological innovation. Academy of Management Review, 28: 257-274.

Hollander, S. 1965. The sources of increased efficiency: A study of DuPont rayon plants. Cambridge, MA: MIT Press.

Jacobides, M. G., \& Billinger, S. 2006. Designing the boundaries of the firm: From "make, buy, or ally" to the dynamic benefits of vertical architecture. Organization Science, 17: 249-261.

Jensen, M. B., Johnson, B., Lorenz, E., \& Lundvall, B.-Å. 2007. Forms of knowledge and modes of innovation. Research Policy, 36: 680-693.

Jeppesen, L. B. 2005. User toolkits for innovation: Consumers support each other. Journal of Product Innovation Management, 22: 347-363.

Jeppesen, L. B., \& Frederiksen, L. 2006. Why do users contribute to firm-hosted user communities? The case of computer-controlled music instruments. Organization Science, 17: 45-63.

Lakhani, K. R., \& von Hippel, E. 2003. How open source software works: "Free" user-to-user assistance. Research Policy, 32: 923-943.

Langlois, R. N., \& Robertson, P. L. 1992. Networks and innovation in a modular system: Lessons from the microcomputer and stereo component industries. Research Policy, 21: 297-313.

Lee, K. R. 1996. The role of user firms in the innovation of machine tools: The Japanese case. Research Policy, 25: 491-507.

Leonard-Barton, D. 1988. Implementation as mutual adaptation of technology and organization. Research Policy, 17: 251-267.

Leonard-Barton, D. 1992. The factory as a learning laboratory. MIT Sloan Management Review, 34(1): 23-38.

Lerner, J., \& Tirole, J. 2002. Some simple economics of open source. Journal of Industrial Economics, 50: 197-234.

Lettl, C., Herstatt, C., \& Gemuenden, H. G. 2006. Learning from users for radical innovation. International Journal of Technology Management, 33: 25-45.

Lhuillery, S., \& Bogers, M. 2006. Measuring user innovation: What can a standard innovation survey tell us? Paper presented at the International Conference on Science, Technology and Innovation Indicators: History and New Perspectives, Lugano. 
Lilien, G. L., Morrison, P. D., Searls, K., Sonnack, M., \& von Hippel, E. 2002. Performance assessment of the lead user idea-generation process for new product development. Management Science, 48: 1042-1059.

Lundvall, B.-A. 1988. Innovation as an interactive process: From user-producer interaction to the national system of innovation. In G. Dosi, C. Freeman, R. R. Nelson, G. Silverberg, \& L. Soete (Eds.), Technical change and economic theory: 349-369. London: Pinter.

Lüthje, C. 2004. Characteristics of innovating users in a consumer goods field: An empirical study of sport-related product consumers. Technovation, 24: 683-695.

Lüthje, C., \& Herstatt, C. 2004. The lead user method: An outline of empirical findings and issues for future research. R\&D Management, 34: 553-568.

Lüthje, C., Herstatt, C., \& von Hippel, E. 2005. User-innovators and "local" information: The case of mountain biking. Research Policy, 34: 951-965.

Morrison, P. D., Roberts, J. H., \& von Hippel, E. 2000. Determinants of user innovation and innovation sharing in a local market. Management Science, 46: 1513-1527.

Myers, S., \& Marquis, D. 1969. Successful industrial innovations. Washington, DC: National Science Foundation.

Nelson, R. R., \& Winter, S. G. 1982. An evolutionary theory of economic change. Cambridge, MA: Belknap.

Nonaka, I. 1994. A dynamic theory of organizational knowledge creation. Organization Science, 5: 14-37.

Ogawa, S. 1998. Does sticky information affect the locus of innovation? Evidence from the Japanese conveniencestore industry. Research Policy, 26: 777-790.

Ogawa, S., \& Piller, F. T. 2006. Reducing the risks of new product development. MIT Sloan Management Review, 47(2): 65-71.

Oliveira, P., \& von Hippel, E. 2009. Users as service innovators: The case of banking services. Working paper no. 4748-09, MIT Sloan School of Management.

Organization for Economic Cooperation and Development. 1997. The measurement of scientific and technological activities: Proposed guidelines for collecting and interpreting technological innovation data (Oslo Manual) (2nd ed.). Paris: Organization for Economic Cooperation and Development.

Piller, F. T., \& Walcher, D. 2006. Toolkits for idea competitions: A novel method to integrate users in new product development. R\&D Management, 36: 307-318.

Pisano, G. P. 1994. Knowledge, integration, and the locus of learning: An empirical analysis of process development. Strategic Management Journal, 15: 85-100.

Polanyi, M. 1958. Personal knowledge: Towards a post-critical philosophy. Chicago: Routledge \& Kegan Paul.

Prahalad, C. K., \& Ramaswamy, V. 2003. The future of competition: Co-creating unique value with customers. Boston: Harvard Business School Press.

Raasch, C., Herstatt, C., \& Balka, K. 2009. On the open design of tangible goods. R\&D Management, 39: $382-393$.

Raasch, C., Herstatt, C., \& Lock, P. 2008. The dynamics of user innovation: Drivers and impediments of innovation activities. International Journal of Innovation Management, 12: 377-398.

Reinganum, J. F. 1983. Uncertain innovation and the persistence of monopoly. American Economic Review, 73: 741-748.

Rice, R. E., \& Rogers, E. M. 1980. Reinvention in the innovation process. Knowledge: Creation, Diffusion, Utilization, 1: 499-514.

Riggs, W., \& von Hippel, E. 1994. Incentives to innovate and the sources of innovation: The case of scientific instruments. Research Policy, 23: 459-469.

Rosenberg, N. 1982. Inside the black box: Technology and economics. Cambridge, UK: Cambridge University Press.

Rosenkopf, L., \& Nerkar, A. 2001. Beyond local search: Boundary-spanning, exploration, and impact in the optical disk industry. Strategic Management Journal, 22: 287-306.

Rothwell, R. 1977. The characteristics of successful innovators and technically progressive firms. $R \& D$ Management, 3: 191-206.

Rothwell, R., \& Gardiner, P. 1985. Invention, innovation, re-innovation and the role of the user: A case study of British hovercraft development. Technovation, 3: 167-186.

Sawhney, M., Verona, G., \& Prandelli, E. 2005. Collaborating to create: The Internet as a platform for customer engagement in product innovation. Journal of Interactive Marketing, 19(4): 4-17.

Shah, S. K. 2006. Motivation, governance, and the viability of hybrid forms in open source software development. Management Science, 52: 1000-1014. 
Shah, S. K., \& Tripsas, M. 2007. The accidental entrepreneur: The emergent and collective process of user entrepreneurship. Strategic Entrepreneurship Journal, 1: 123-140.

Shaw, B. 1985. The role of the interaction between the user and the manufacturer in medical equipment innovation. R\&D Management, 15: 283-292.

Simon, H. A. 1965. Administrative behavior: A study of decision-making processes in administrative organization. New York: Free Press.

Skiba, F., \& Herstatt, C. 2009. Users as sources for radical service innovations: Opportunities from collaboration with service lead users. International Journal of Services Technology and Management, 12: 317-337.

Slaughter, S. 1993. Innovation and learning during implementation: A comparison of user and manufacturer innovations. Research Policy, 22: 81-95.

Smith, A. 1776/1999. An inquiry into the nature and causes of the wealth of nations. London: Penguin.

Spital, F. 1979. An analysis of the role of users in the total R\&D portfolios of scientific instrument firms. Research Policy, 8: 284-296.

Stuermer, M., Spaeth, S., \& von Krogh, G. 2009. Extending private-collective innovation: A case study. $R \& D$ Management, 39: 170-191.

Sutton, R. I., \& Staw, B. M. 1995. What theory is not. Administrative Science Quarterly, 40: 371-384.

Teece, D. J. 1986. Profiting from technological innovation: Implications for integration, collaboration, licensing and public policy. Research Policy, 15: 285-305.

Tietz, R., Morrison, P. D., Lüthje, C., \& Herstatt, C. 2005. The process of user-innovation: A case study on user innovation in a consumer goods setting. International Journal of Product Development, 2: 321-338.

Tripsas, M. 1997. Unraveling the process of creative destruction: Complementary assets and incumbent survival in the typesetter industry. Strategic Management Journal, 18: 119-142.

Tushman, M. L., \& Anderson, P. 1986. Technological discontinuities and organizational environments. Administrative Science Quarterly, 31: 439-465.

Urban, G. L., \& von Hippel, E. 1988. Lead user analyses for the development of new industrial products. Management Science, 34: 569-582.

Utterback, J. M. 1994. Mastering the dynamics of innovation. Boston: Harvard Business School Press.

Vargo, S. L., \& Lusch, R. F. 2004. Evolving to a new dominant logic for marketing. Journal of Marketing, 68(1): $1-17$.

von Hippel, E. 1976. The dominant role of users in the scientific instrument innovation process. Research Policy, 5: 212-239.

von Hippel, E. 1978. A customer-active paradigm for industrial product idea generation. Research Policy, 7: 240266.

von Hippel, E. 1986. Lead users: A source of novel product concepts. Management Science, 32: 791-805.

von Hippel, E. 1988. The sources of innovation. New York: Oxford University Press.

von Hippel, E. 1994. "Sticky information" and the locus of problem solving: Implications for innovation. Management Science, 40: 429-439.

von Hippel, E. 2005. Democratizing innovation. Cambridge, MA: MIT Press.

von Hippel, E. 2007. Horizontal innovation networks: By and for users. Industrial and Corporate Change, 16: 293 315.

von Hippel, E., \& Katz, R. 2002. Shifting innovation to users via toolkits. Management Science, 48: 821-833.

von Hippel, E., \& Tyre, M. J. 1995. How learning by doing is done: Problem identification in novel process equipment. Research Policy, 24: 1-12.

von Hippel, E., \& von Krogh, G. 2003. Open source software and the "private-collective" innovation model: Issues for organization science. Organization Science, 14: 209-223.

von Krogh, G., \& von Hippel, E. 2003. Special issue on open source software development. Research Policy, 32: 1149-1157.

von Krogh, G., \& von Hippel, E. 2006. The promise of research on open source software. Management Science, 52: $975-983$.

Voss, C. A. 1985. The role of users in the development of applications software. Journal of Product Innovation Management, 2: 113-121.

West, J., \& Gallagher, S. 2006. Challenges of open innovation: The paradox of firm investment in open-source software. R\&D Management, 36: 319-331.

Whetten, D. A. 1989. What constitutes a theoretical contribution? Academy of Management Review, 14: 490-495. 